\title{
A Magyar Királyi Honvédség páncélozott eszközökkel felszerelt felderítő csapatai
}

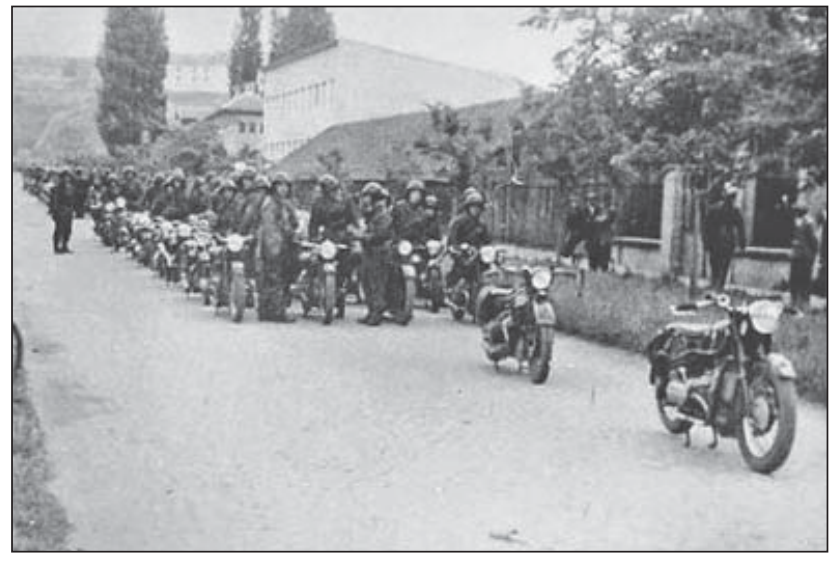

102. ábra. Motorkerékpáros alegység Újvidéken

A Sándor-csoport elővédje 1941. április 13-án 19.30-kor, a zöm 20 órára érte el az Ujvidéktől északra lévő felrobbantott csatornahidat és felvette az összeköttetést az 1. gépkocsizó dandárral.
Itt tájékoztatást kapott az 1. gépkocsizó dandár parancsnokától, hogy kétezrednyi ellenséges katona a felszerelését hátrahagyva délkeletre Titel irányába menekült az üldözés elől. A Sándor-csoport kimerültsége és megfelelő erő hiánya miatt csak 14-én hajnalban tudta folytatni menetét, miután éjfél előtt beérkezett a Sándor-csoport még Szabadka előtt lemaradt harmadik lépcsője. Allományában a Hervay Béla százados parancsnoksága alatt álló 3. puskás század, a felderítő-zászlóalj 2. kisharckocsi-százada (parancsnoka Mészöly Géza százados) és a 12. kerékpáros üteg volt. Ez a csoport kapta feladatul, hogy április 14-én hajnali 4 órakor induljon üldözésükre Sajkásszentivánon át Titel irányában. Feladata volt még, hogy kiérkezve a Dunához, vegye birtokba a dunai átkelőt, akadályozza az ellenség átjutását a déli partra és vegye fel a kapcsolatot a már ott lévő német csapatokkal. ${ }^{176}$ Mészöly Géza százados a kisharckocsi-század parancsnoka a „kikülönített századával Titelnél a zászlóaljtól teljesen elszigetelten gyors, határozott, merész és ötletes fellépésével az ellenséget meglepte, egy ötszörös túlerőt fegyverzett le" - olvasható a kitüntetési felterjesztésben. Közel 2000 fős ellenséges alakulat kapitulált. A csoportosítás másnap csatlakozott a dan-

103. ábra. Délvidéki bevonulás Muravidéken - Alsólendván (Fortepan)

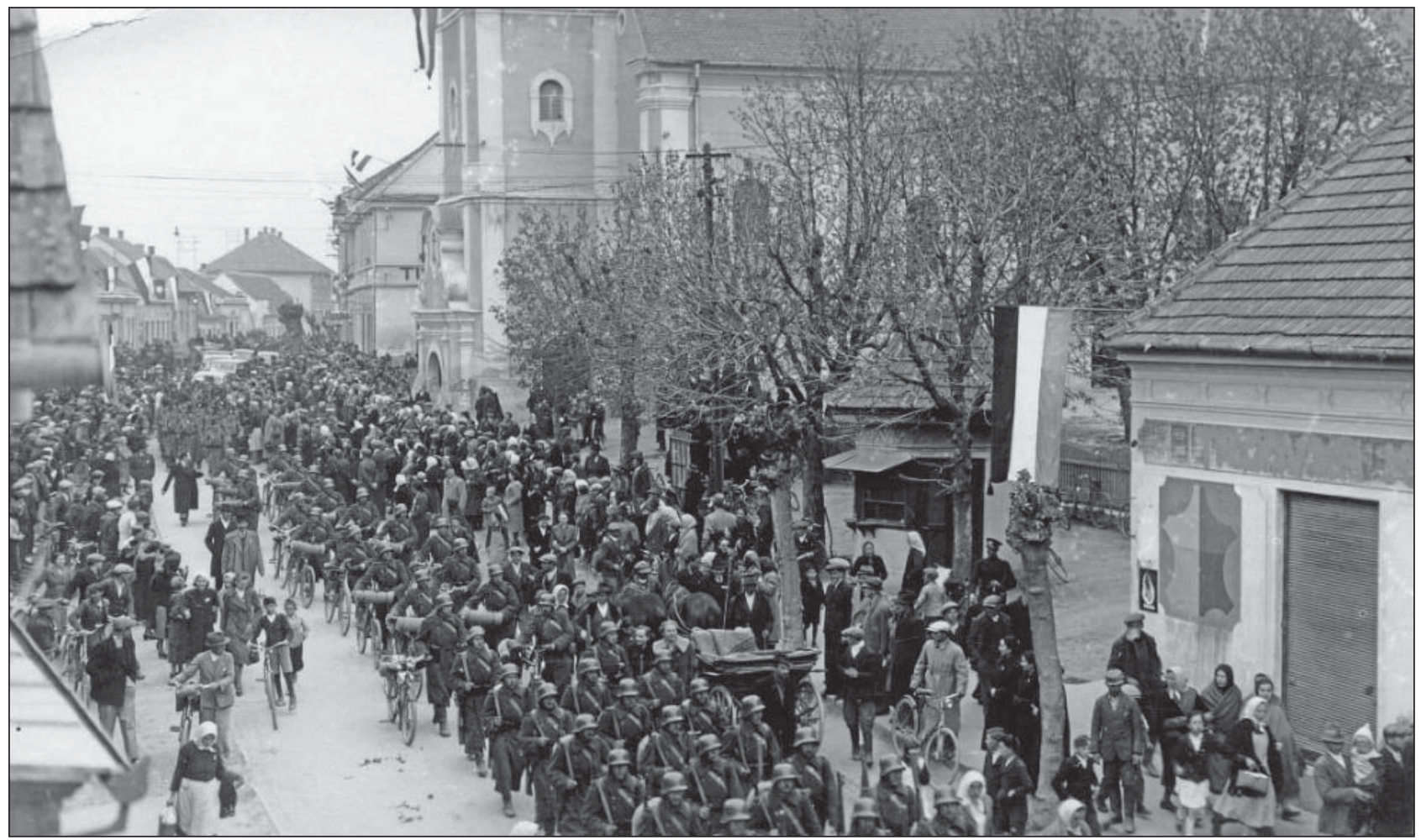




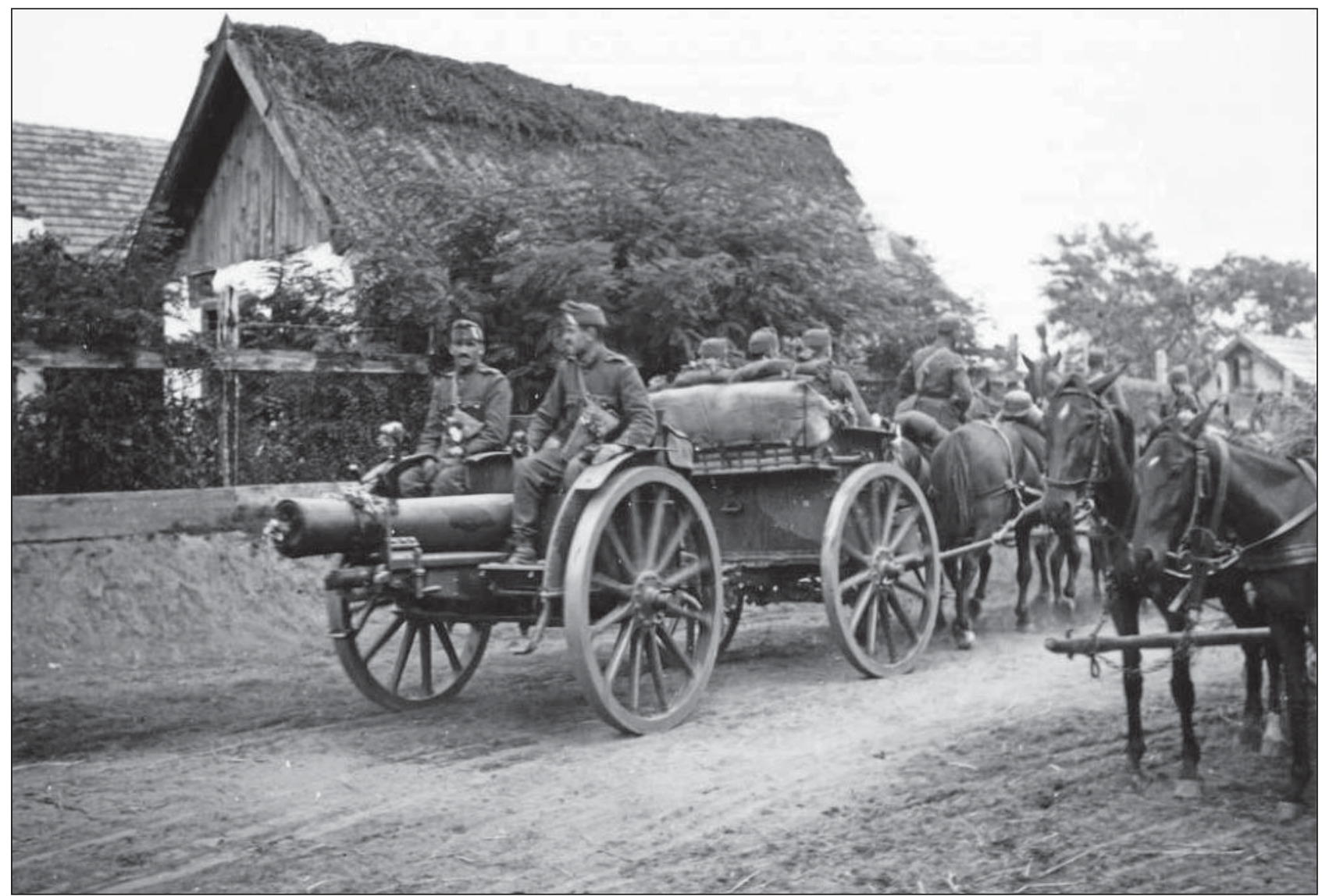

104. ábra. Lovas tüzéregység menetben (Fortepan 43580)

dár zöméhez, de előtte még sikeres helységharcot folytatott Bácsszőregnél. ${ }^{177}$

Amikor a Sándor-csoport már Újvidék felé tört elöre, a 2. gépkocsizó dandár zöme még csak Szabadkán igyekezett keresztülvergődni.

A zöm élén lévő 5. zászlóalj parancsnoka, miután 13-án 08.45-kor (közel 8 órás várakozás után - S.R.) megtudta, hogy a műút helyreállítására még estig várniuk kell, zászlóaljával kitért és a dűlőutak kihasználásával újból elérte a műutat. A zászlóaljjal menetelt a 2. gépkocsidandár parancsnoka és a Sándor-csoport harmadik lépcsője is. A múútra kiérkezve a dandár vette a Sándor-csoport jelentését, hogy folytatja a menetét Újvidék felé. Ekkor indították utána a 3. menetlépcsőt, amely így érkezett be 23.30kor Újvidékre.

A 2. gépkocsizó dandár parancsnoka és az 5. gépkocsizó zászlóalj 13-án 16.40-kor ért be Szabadkára és ekkor kapta meg a hadtestparancsnok 12-én éjfélkor kiadott, a 13-i előnyomulásra szóló parancsát (!), amely akkor még a Temerin, Káty, Újterületére való kiérkezést és részeivel Újvidék és Titel birtokba vételét határozta meg. Mivel a 13-án délelőtt kiadott kiegészítő intézkedésről még nem tudott, ezért elhatározta, hogy a Sándor-csoporttal folytatja az előretörését Újvidékre, a dandár zöm élén menetelő 5. gépkocsizó zászlóaljjal pedig Titelre tör előre, a többi részeivel Temerin, Káty területére menetel.

Szabadkán a csetnikekkel folytatott rövid csatározás után a dandár parancsnoka az 5 . gépkocsizó zászlóaljjal folytatta menetét, és 17.50-kor Topolyára, majd 19.50-re Szenttamás elé érkezett.

Menetközben vette a hadtestparancsnok délelőtt kiadott kiegészítő intézkedését, amely szerint már az eredetileg
2. gépkocsizó dandár részére szánt feladatokat az 1. gépkocsizó dandár kapta meg. Mivel az új intézkedés nem tartalmazott új feladatot a 2. gépkocsizó dandár számára, a parancsnok megmaradt az előbb említett elhatározása mellett. ${ }^{178}$

A gyorshadtest parancsnoksága annak érdekében, hogy a parancsnok személyesen vezethesse a Szenttamásról Újvidék irányába visszavonuló ellenség bekerítését, a csapatokhoz közelebb, Kula községbe települt.

A kiadott intézkedés is ezt tükrözte; alapgondolata szerint az 1. gépkocsizó dandár zömével Újvidék felől északra, a Sándor-csoport Szenttamástól délre a 2. lovasdandár zömével együtt, a lovasdandár részeivel pedig a csatornán átkelve keletről és nyugatról, a Szenttamásról a visszavonuló ellenséget teljesen bekeríti és megsemmisíti.

Ezt a tervet azonban addigra az események már részben túlhaladták, részben pedig a kialakult események a végrehajtását meggátolták. Így például a Sándor-csoport újvidéki előretörésével az ellenséget nyugatra szorította, az 1. gépkocsizó dandár Petrőcnél felszámolta az ellenséget, a 2. lovasdandár 15. kerékpáros zászlóalja csak éjjel tudott átjutni a csatorna déli partjára Újverbásznál, és az 1. gépkocsizó dandár pedig csak késő este ért ki újvidékre, ahonnan a felrobbantott hidak miatt nem tudott átkelni a Ferenc József-csatorna északi oldalára.

A 2. gépkocsizó dandár - amely lemaradt eredeti feladatának teljesítéséről - 17.45kor új feladatot kapott, hogy gyorsítsa meg („folytassa a legnagyobb eréllyel”) a déli előrenyomulását és még aznap érjen ki Topolya, Kulán át Bácskeresztúr, Torzsa, Úrszentiván, Pincéd területére, ahol majd beszállásol. Részeivel ki kellett jutnia Palánkára. Ezt a feladatot az 5. gépkocsizászlóalj menetének megkezdése- 
kor kapta, ezért a zászlóaljat kénytelen volt megfordítani Titel irányából. Az ellentétes irányban megindította menetét és a dandárparancsnokkal együtt 22.30-ra érkezett Kulára ahol beszállásoltak

A 6. gépkocsizó zászlóalj - amely még mindig Palics és Szabadka között ismételt csetnik rajtaütések között vesztegelt - csak 14-én, 8-9 óra között tudott beérkezni Kulára.

A dandár 12. kerékpáros zászlóalja, amely 13-án reggel 7.30-kor kezdte meg a menetét, 10 órakor Szegeden áthaladva, este 20 órára érkezett Ludasra. A 2. gépvontatású tüzérosztály is csak 18-19 óra között érkezett Palicsfürdőre, mert csetnikharcok késleltették.

A 2. gépkocsizó dandár a 13/14-ére virradó éjszakáján Újvidéktől Palicsfürdőig elhúzódó csoportosításban, elaprózva helyezkedett, egyes kötelékei elszállásolva, mások nehéz éjszakai meneteket végrehajtva. ${ }^{179}$ (Ezek alapján a dandár a kapott parancsot ismét nem tudta teljesíteni, vagy másképpen fogalmazva a gyorshadtest ismét egy - az adott helyzetben - végre nem hajtható intézkedést adott ki - S.R.)

Az 1. lovasdandár a Topolya, Bajma, Jakabszállás területére való előrenyomulást kapta feladatul.

A gépkocsizó részek közül a 3 . gépvontatású könnyű tüzérosztály 14.15-re, a páncélos zászlóalj törzse és a páncélgépkocsi-százada 15 órára érkezett meg Topolyára.

A dandár lovas légvédelmi gépágyús ütege 6 órára érkezett meg Bajmokra, onnan 17.50-kor indult Pacsérra, ahol csetnik harcokba keveredett, valamint a nagy torlódások miatt csak hajnalban folytathatta menetét Topolyára, ahová 14-én 09.30-kor érkezett be.

Topolyán 17-18 óra között csetnik támadás volt, aminek elfojtásában az ott lévő csapatok részt vettek.

A lovas részeket Bajmokra csoportosították. A 4. huszárezred I. osztálya Bajmokon maradt, a II. osztálya még csak Kiskőrösön volt, és éffélkor kezdte meg az előrevonását, így 16 órára érkezett Bácsalmásra és ott éjjelezett. Hajnali 3 órakor kezdte meg elörevonását Bácsalmáson át a 3. huszárezred I. osztály fél állománya, valamint az 5. és a 6 páncéltörő ágyús század is, végül 17 órakor érkeztek meg Bajmokra. A II. osztály megmaradt része 22 órakor érkezett Bácsalmásra. A dandár 1. lovas tüzérosztálya 13-án még csak Kiskunmajsán volt vasúti kirakodáson.

A dandár 13. és 14. kerékpáros zászlóaljainak első részei Kecskeméten kirakodtak, menetet hajtottak végre Mélykútra, és ott éjjeleztek. ${ }^{180}$

Az 1. gépkocsizó dandár feladata az Újvidék-Káty-Újvidék északi területének biztosítása, valamint egy megerősített különítmény kiküldésével Újfutak és Titel területének kézben tartása volt. Az április 13-án késő este már Újvidékre beérkezett parancsnokságok és csapatok ellen, a csetnikek kisebb szünetekkel egész éjszaka rejtett helyekről tűzrajtaütéseket hajtottak végre és tevékenységüket másnap is folytatták, amíg a kijelölt erők át nem fésülték alaposan a várost. ${ }^{181}$

Reggel a dandárparancsnok Kátyra rendelte a 3. gépkocsizó zászlóalj két századát, amelyek harc nélkül elfoglalták a községet és többek között 6 löveget zsákmányoltak.

Egy másik megerősített század pedig a 4. gépkocsizó zászlóalj egy századával együtt elérte Titelt, aminek elfoglalása előtt Temerin és Sajkagyörgye területén rajtaütöttek egy szerb ezred erejü csoportosításon, amely rövid harc után letette a fegyvert.

A 2. gépkocsizó zászlóalj Hódság és Paripás területén maradt vissza. 14-én 6 órakor megkezdte menetét Úrszentiván, Ó-Sóve, Dunagáloson át Ófutakra, ahová 12 órakor érkezett meg. Itt 14 órakor vette az Újvidékre való azonnali bevonulási parancsot, hogy megtisztítsa a fütőház

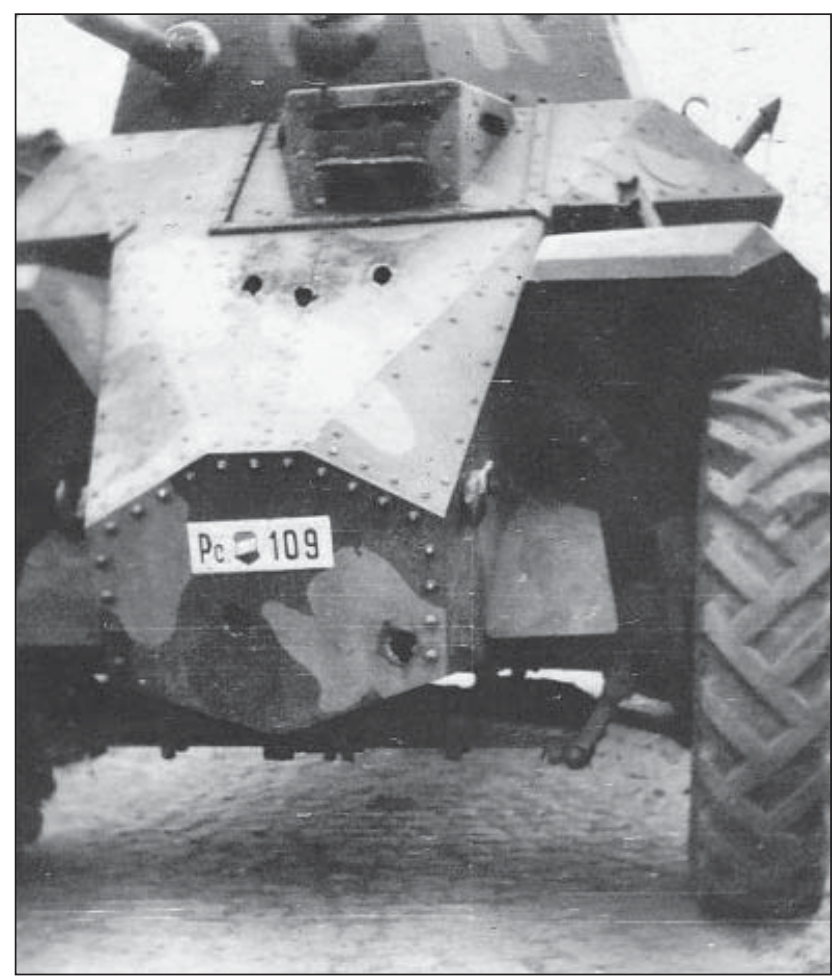

105. ábra. Kilőtt Csaba páncélautó

és a repülőtér környékét a csetnikektől. A 14. kerékpáros zászlóalj Új-Futakon és Begecsen maradt.

A IV. kerékpáros zászlóalj az 1. gépkocsizó dandár szárnyát biztosítva Paripás, Pincéd, Úrszentiván, Ó-Sóve, Ó-kéren át Újvidékre való menetre kapott parancsot. A 06.30-kor induló zászlóalj 11 óra körül ért Bácsszőreg pusztához, ahol harcba keveredett az orvlövészekkel. 11.30-kor parancsot kapott az Újvidékre való bevonulásra, de a felrobbantott hidak miatt vissza kellett fordulnia Petrőcre, és csak késő este érkezett Új-Futakra, ahol éjjelezett. 5-én reggel visszalépett a IV. hadtest alárendeltségébe.

A 2. gépkocsizó dandár parancsnoksága Kulán éjjelezett, ahol egész éjszaka tartott a tűzharc a csetnikkel. A2. gépkocsizó dandár az Úrszentiván-Torzs-Bácskereszttúr-Pincéd térség elfoglalását kapta feladatul, és egy tüzérséggel megerősített biztosító csoport kiküldését rendelte el Palánkára.

Ennek alapján a megerősített 5 . gépkocsizó zászlóalj 12 órakor megkezdte a menetét Pincéden át Palánkára, de az utak járhatatlansága miatt kénytelen volt visszafordulni és menetcélját csak a Bács-Keresztúr, Hódság és Bácson át tudta megközelíteni. Palánkára 16.30-kor érkezett be.

6. gépkocsizó zászlóalj megerősítve a gépvontatású tüzérosztály 2. ütegével 12 órakor indult Kuláról és 18-19 óra között érkezett be Torzsára.

A 12. kerékpáros zászlóalj a kialakult nagy torlódások miatt csak 14-én 08.30-kor folytathatta menetét Palicsfürdőről és 14 órára ért Kulára. A kulai utcai harcok miatt a tervezett 16 óra helyett csak 18.30-kor tudott újra elindulni Pincéd felé, de a rossz útviszonyok miatt 23 óráig csak Liliomosig jutott el, és ott éjjelezett.

Sándor alezredes csoportja 14-én délelőtt Újvidék északi részét tisztította meg a csetnikektől. 10.30-kor vette a dandár parancsát, hogy azonnal induljon Szenttamáson át Kulába. A csoport az ejtőernyős századot a zsákmány őrzésére hátrahagyva, 14 órakor kivonult Újvidékről és 
